Research Article

\title{
Potential of Wild Yeast from Banana to Control Colletotrichum musae Fungi Caused Anthracnose Disease and Its Short Antagonistic Mechanism Assay
}

\author{
Anton Muhibuddin *, Dewi Maratus Sholihah \\ Department of Plant’s Pest and Disease, Agriculture Faculty, Brawijaya University, Malang 65145, Indonesia
}

Article history:

Submission May 2017

Revised November 2017

Accepted December 2017

*Corresponding author:

E-mail: antonmhb@gmail.com

\begin{abstract}
Anthracnose caused by Colletotrichum musae is one of several important diseases in banana fruit. An effective, cheap, and safe control method is necessary as a postharvest disease control alternative. This research aimed to obtain and identify wild yeast from banana which was isolated from its peel that had antagonist ability effectively in controlling anthracnose disease of banana fruit. This research was started with isolation of $C$. musae and yeast from banana, followed by in vivo assay with count percentage antagonist level, slide culture, and in vivo assay to know pathogen incubation stage and incident disease level. The yeast that isolated from Ambon variety was Candida sp., Pichia sp., and Metchnikowia sp. from Kepok variety respectively.
\end{abstract}

Keywords: Colletotricum musae, Pichia sp., Metchnikowia sp., antagonist

mechanism

\section{Introduction}

Yeast is a group of unicellular fungi which has many benefits. In agriculture, yeast also has a potency as biocontrol. As a biocontrol yeast can be found on fruit [1]. Banana is one of famous fruits by common people. The disease is anthracnose caused by Colletotricum musae which is considered as one of the most important diseases of banana. It deteriorates the quality and nutritive value of the fruits and renders them unfit for marketing and consumption. It has level damage on banana till 100\% [2]. Some banana has different resistance depend on their varieties. Time average that pathogen needed to infect is 3.5 days on unripening condition. The damage intensity is different in each variety, it may be caused by thick peel [3].

As far as now, banana anthracnose problem has not been completely overcome yet. Potency of microbial yeast contained in the banana was important. It was necessary to study its ability in controlling anthracnose. Yeast isolated from the ripe banana of susceptible and resistant variety has po- tency to over-come C. musae. To obtain ripe bananas, one way is used to accelerate the ripening of fruit by adding carbide acid that can increase temperature until $33^{\circ} \mathrm{C}$ [4]. At $20-40^{\circ} \mathrm{C}$ temperature, not all yeast genus can survive. It is because of the environment factors affect microbe's survivability [5, 6]. Diversity of thermotolerant yeast from banana peel needs to be discovered along with its potency as biocontrol agent for C. musae. Toward, systematic expiration of yeast is needed for studying more details [7].

Purpose of the research was to find out yeast diversity from peel of Kepok and Ambon banana varieties on $40^{\circ} \mathrm{C}$ temperature and to study their yeast potencies in controlling anthracnose on banana by in vitro and in vivo assay.

\section{Material and Methods}

The research was held on January-June, 2016 in Plant Pest and Disease Department, Mycology Laboratory, Agriculture Faculty Brawijaya University. The research was held by exploration and experimental methods. Exploration method was

\section{How to cite:}

Muhibuddin A, Sholihah DM (2019) Potential of Wild Yeast from Banana to Control Colletotrichum musae Fungi Caused Anthracnose Disease and Its Short Antagonistic Mechanism Assay. Journal of Tropical Life Science 9 (1): 35 - 41 . doi: 10.11594/jtls.09.01.06 
implemented by isolating yeast from Ambon and Kepok banana varieties subsequently treated temperature $40^{\circ} \mathrm{C}$. Experimental method was carried out by in vitro and in vivo assays to know the yeast antagonist ability against $C$. musae.

\section{Isolation of thermotolerant yeast and C. musae}

C. musae was isolated by growing spores obtained from bananas that showed anthracnose symptom, the spore was planted on PDA. Yeast isolated from Kepok and Ambon banana varieties were categorized as 6 indexes of ripening. As much as $10 \mathrm{~g}$ of banana peel was shaken with 90 $\mathrm{mL}$ aquadest with $120 \mathrm{rpm}$ speed for 24 hours. Immersion diluted water, was diluted on $10^{-3}, 10^{-4}$ and $10^{-5}$ respectively, and then it was suspended in $50 \mathrm{~mL}$ aquadest and planted on YMA by spread plate method. Yeast then was screened on $40^{\circ} \mathrm{C}$ temperature for 90 minutes and incubated for 3 4 days $[8,9]$.

Yeast microscopic and macroscopic identifications refer to the Yeast 5th Edition [1]. Macroscopic characteristics consisted of the appearance of yeast colonies on petri dish which were the shape of colony, color, texture, margin, and elevation. Microscopic characteristics consisted of the appearance of cell shape, size, reproduction type, budding type, and pseudo hyphae existence. Microscopic identification was held after yeast incubated for 24 hours under microscope with 400× magnifications.

\section{In vitro assay thermotolerant yeast against $C$. musae \\ Percentage of relative inhibition level}

The assay was done by planting thermotolerant yeast with $C$. musae in petri dish with $\Phi 9 \mathrm{~cm}$ diameter. We used PDA medium. 1 loop yeast stretched crossway on PDA, C. musae laid between the yeast inoculation line for $3 \mathrm{~cm}$ [10]. Observation had been done for 6 days by counting $C$. musae colony growth wide, then percentage relative inhibition level was counted by formula:

$$
T H R=\frac{d k-d p}{d k}
$$

Note:

THR: Percentage of relative inhibition level formed by pathogen

$\mathrm{dk}$ : Number of colonies radius $(\mathrm{r} 1+\mathrm{r} 2)$ pathogens without treatment (control)

$\mathrm{dp}$ : Number of colonies radius $(\mathrm{r} 1+\mathrm{r} 2)$ pathogens with yeast treatment

\section{Slide culture method}

Slide culture method was used to know antagonist mechanism between yeast and C. musae under microscopic observation. Slide culture method was done by putting $1 \mathrm{~cm}^{2}$ PDA on glass, yeast and pathogen stretched on PDA with $5 \mathrm{~mm}$ distance, then covered by cover glass. This culture then incubated for 4 days with moist and aseptic conditions. After 4 days, the yeast and C. musae viewed by observing the interactions [11].

\section{In vivo assay thermotolerant yeast against C. mu- sae}

All the fruits used were surface cleaned with flowing water then air dried at room temperature and disinfected with alcohol 70\%. Every fruit syringed with yeast suspension $\left(10^{7} \mathrm{cell} / \mathrm{mL}\right)$ until wet. Fruits' surfaces were wounded by sterilized pin ( $\pm 1 \mathrm{~mm}$ depth from the surface). Three wounds were made per fruit and the wounds were inoculated with 1 drop of $C$. musae suspension $\left(10^{6} \mathrm{cell} / \mathrm{mL}\right)$. The inoculated fruits were placed on plastic trays and enclosed in clean plastic wrap to maintain the humidity and incubated at room temperature for 6 days. Observation had been done every day until the first symptom appeared. After 6 days, the wound with symptom observed by counting the percentage of incidence level by the formula:

$$
I D=\frac{n}{N} \times 100 \%
$$

Note:

ID: Incidence of disease

$\mathrm{n}$ : Number of points inoculations that shown symptoms of illness

$\mathrm{N}$ : Number of points of inoculation were observed

\section{Statistical analysis}

Data from antagonist test had been analyzed using Analysis of Variance (ANOVA) and continued with Least Significant Different (LSD) test at $5 \%$ level for post hoc test.

\section{Results and Discussion \\ Identification of the isolated fungi from posthar- vest diseased fruit}

C. musae spore obtained by spore isolation from banana with the symptom of anthracnose on 
Table 1. Macroscopic and microscopic appearances of thermotolerant yeasts obtained

\begin{tabular}{|c|c|c|c|c|c|c|}
\hline \multirow{2}{*}{ No. } & \multirow{2}{*}{ Species } & \multicolumn{5}{|c|}{ Macroscopic Characteristic (Colony) } \\
\hline & & Colour & Texture & Surface & Elevation & Margin \\
\hline 1. & Candida sp. & White bone & Thick & Smoth & Curved & Irreguler \\
\hline 2. & Pichia sp. & White bone & Thick & Smoth & Curved & Irreguler \\
\hline 3. & Metchnikowia sp. & White bone & Thick & Slippery & Curved & Flat \\
\hline \multirow[b]{2}{*}{ No. } & & \multicolumn{5}{|c|}{ Microscopic characteristic (Cell) } \\
\hline & Species & Shape & Size $(\mu m)$ & Reproduction & $\begin{array}{c}\text { Budding } \\
\text { type }\end{array}$ & Pseudohiphae \\
\hline 1. & Candida sp. & Oval & $4.48-5.02$ & Budding & Multilateral & Present \\
\hline 2. & Pichia sp. & Bulat & $4-9$ & Budding & Multilateral & Absent \\
\hline 3. & Metchnikowia sp. & Bulat & $4.13-4.62$ & Budding & Multilateral & Absent \\
\hline
\end{tabular}

Table 2. Average percentage relative inhibition level

\begin{tabular}{cccrrrrr}
\hline \multirow{2}{*}{ No. } & Yeast treatment & \multicolumn{6}{c}{ Percentage relative inhibition level (\%) } \\
\cline { 3 - 8 } & & 1 DAI & 2 DAI & 3 DAI & 4 DAI & 5 DAI & 6 DAI \\
\hline 1. & Control & 0 & $0 \mathrm{a}$ & $0 \mathrm{a}$ & $0 \mathrm{a}$ & $0 \mathrm{a}$ & $0 \mathrm{a}$ \\
2. & Candida sp. & 0 & $20.89 \mathrm{~b}$ & $6.42 \mathrm{ab}$ & $13.85 \mathrm{ab}$ & $10.41 \mathrm{~b}$ & $0 \mathrm{a}$ \\
3. & Pichia sp. & 0 & $18.48 \mathrm{~b}$ & $14.15 \mathrm{~b}$ & $30.11 \mathrm{~b}$ & $10.83 \mathrm{~b}$ & $8.33 \mathrm{~b}$ \\
4. & Metchnikowia sp. & 0 & $14.39 \mathrm{ab}$ & $9.31 \mathrm{ab}$ & $6.73 \mathrm{ab}$ & $4.58 \mathrm{ab}$ & $0 \mathrm{a}$ \\
\hline
\end{tabular}

Note: values with different letters within columns are significantly different (LSD 5\%)

PDA. The isolated fungal colony was identified as C. musae. On PDA plate it formed white aerial which turned pinkish in color with aged, smooth surface colony. Microscopic appearance showed hyaline and septate hyphae. Cilindrical conidia, aseptate, and the conidial length range 9.73-14.5 $\times 3.08-5 \mu \mathrm{m}$.

Another research reported that on PDA, $C$. musae showed blackish white, pink, and orange colony, it had irregular margin and the rest of isolated yeasts were having smooth margin [2]. Conidia of C. musae isolations were aseptate, hyaline, mostly elipsoid, with length ranging for $10-$ $18 \mu \mathrm{m}$ and $5-9 \mu \mathrm{m}$.

\section{Identification of the isolated thermotolerant yeasts from Kepok and Ambon varieties}

Thermotolerant yeasts obtained from Kepok banana was Pichia sp. and Metchnikowia sp. and from Ambon banana was Candida sp. The result of identification thermotolerant yeasts was performed on Table 1.

In vitro assay thermotolerant yeast against $C$. musae

\section{Percentage of relative inhibition level}

A total of three isolations of thermotolerant yeasts were selected by temperature treatment $40^{\circ} \mathrm{C}$ for 90 minutes. The percentage of relative inhibition level showed on Table 2. Yeast has inhibited pathogen for 5 days, started at 2 until 6 DAI. Candida sp. and Pichia sp. treatments showed fluctuate inhibition level, and Metchnikowia sp. inhibition level had reduced every day until 6 DAI. In 6 DAI, percentage inhibition level of control treatment, Candida sp., and Metchnikowia sp. showed percentage inhibition $0 \%$ and, Pichia sp. percentage was $8.3 \%$.

\section{Slide culture method}

Antagonist mechanism caused by yeast from slide culture method was antibiosis and competition for nutrition and space. On Candida sp. treatment did not show antagonist mechanism (Figure 1b), whereas Pichia sp. treatment showed antibiosis mechanism (Figure 1c) and Metchnikowia sp. with competition mechanism (Figure 1d).

\section{In vivo assay of thermotolerant yeast against $C$. musae}

Thermotolerant yeast treatment did not give effect for percentage incidence disease level and pathogen incubation phase (Table 3). Whereas variety treatment gave effect for percentage incidence disease and incubation pathogen phase (Table 4). Combination of yeast and banana variety 


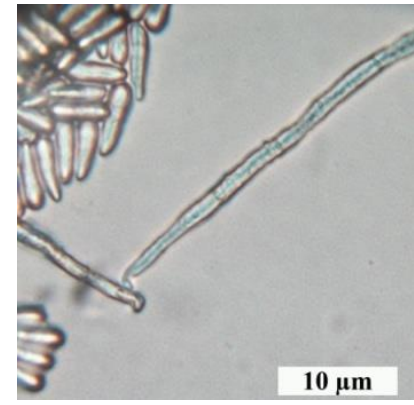

(a)

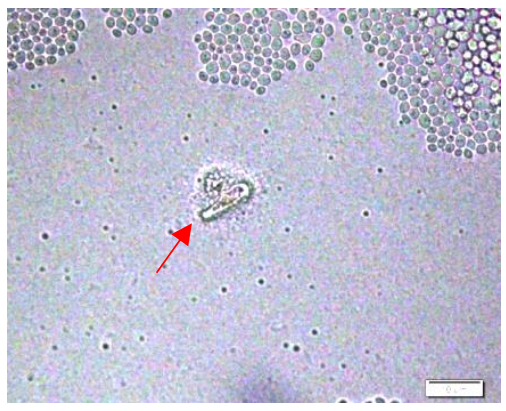

(c)

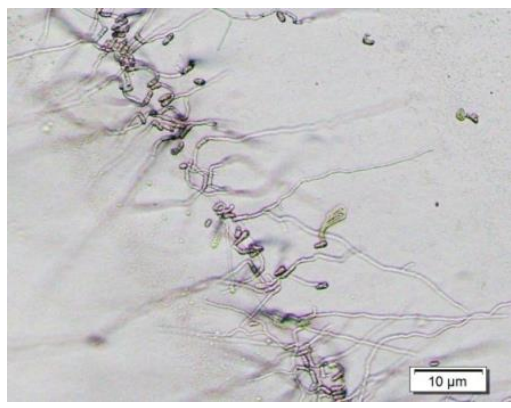

(b)

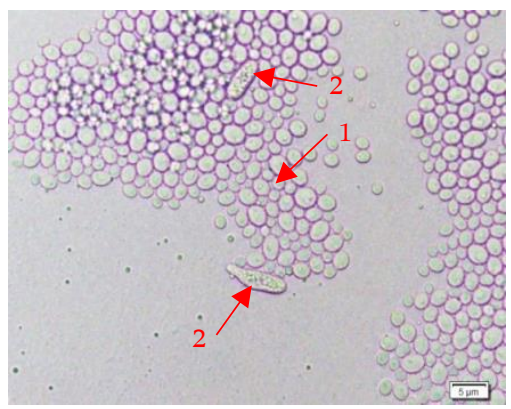

(d)

Figure 1. Antagonist assay by slide culture method: Control (a), Candida sp. (b), Pichia sp. (c) (Lysis of pathogen cell), and Metchnikowia sp. (d) (1. Pathogen cell, 2. Yeast cell)

Table 3. Yeast effect against disease incubation phase and incidence disease level

\begin{tabular}{clcl}
\hline No. & Yeast Treatment & Incidence Disease Level (\%) & Disease Incubation Phase (Day) \\
\hline 1. & Control & $95.23 \mathrm{a}$ & $2.35 \mathrm{a}$ \\
2. & Candida sp. & $90.47 \mathrm{a}$ & $2.42 \mathrm{a}$ \\
3. & Pichia sp. & $90.47 \mathrm{a}$ & $2.50 \mathrm{a}$ \\
4. & Metchnikowia sp. & $95.23 \mathrm{a}$ & $2.42 \mathrm{a}$ \\
\hline
\end{tabular}

Note: Values with different letters within columns are significantly different (LSD 5\%)

Table 4. Banana variety effect against disease incubation phase and incidence disease level

\begin{tabular}{cccc}
\hline No. & Variety Treatment & Incidence Disease Level (\%) & Disease Incubation Phase (Day) \\
\hline 1. & Ambon & $100 \mathrm{a}$ & $2.03 \mathrm{a}$ \\
2. & Kepok & $85.70 \mathrm{~b}$ & $2.82 \mathrm{~b}$ \\
\hline
\end{tabular}

Note: Values with different letters within columns are significantly different (LSD 5\%)

treatments did not affect it (Table 5).

Banana anthracnose starts to show symptom after ripening condition. As far as now, it was informed that C. musae has not been restrained yet, research has been needed to reduce pathogen infection. In unripe condition, symptom has not showed yet because of the unavailability of nutrition for pathogen. It was different with yeast isolation from avocado. Yeast isolation from avocado was effective to reduce anthracnose on avocado [12]. Yeast Rhodotolura sp. and Metchnikowia sp. can reduce Colletotrichum sp. on strawberry and chili [13].

The percentage relative inhibition level and slide culture method showed antibiosis and competition for nutrition and space against $C$. musae growth. Antibiosis mechanism was occurred toxic compound by disturbing permeability cell membrane and destroying cytoplasm of cell pathogen [14]. It showed in Pichia sp. treatment that destroyed cell pathogen close to them (Figure 1c). Not only toxic compound, yeast also produced enzyme like chitinase, protease, and glutanase [15].

Metchnikowia sp. treatment indicated competition for antagonist mechanism. It showed on Figure $1 \mathrm{~d}$, that the yeast cell attached to the pathogen cell. The speed growth of yeast was faster than pathogen in this medium, so it affected competi- 


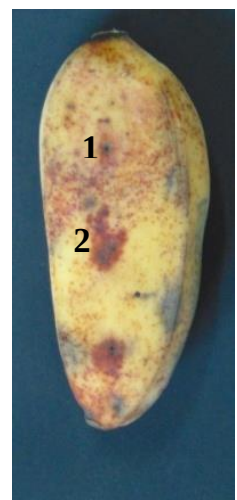

(a)

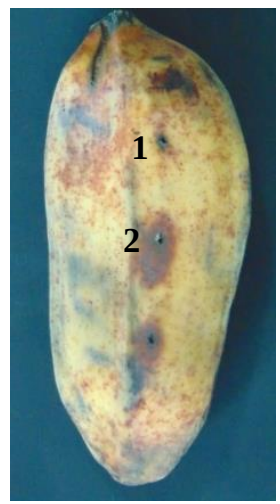

(b)

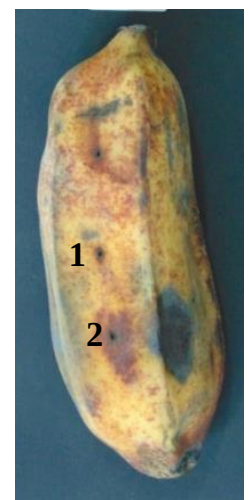

(c)

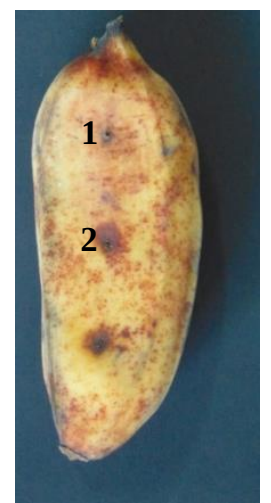

(d)

Figure 2. Incidence disease level on Kepok variety: Control (a), Candida sp. (b), Pichia sp. (c), and Metchnokowia sp. (d) (Note: uninfected (1) and infected (2))

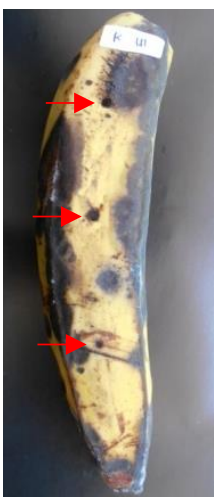

(a)

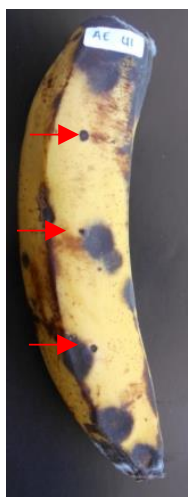

(b)

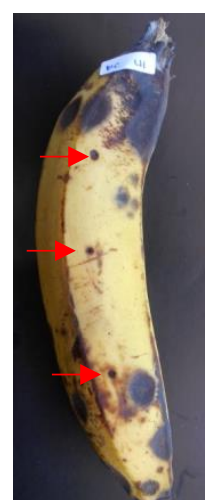

(c)

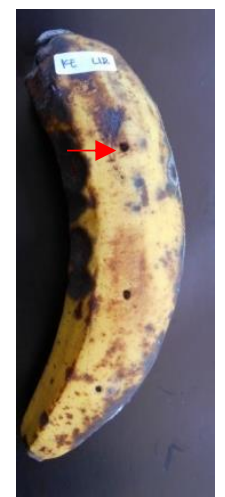

(d)

Figure 3. Incidence disease level on Ambon variety: Control (a), Candida sp. (b), Pichia sp. (c), and Metchnokowia sp. (d) (Note: the sign showed infection of C. musae)

tion for nutrition and space growth. The increased of yeast population decreased nutrition and space for pathogen, and decreased germination ability. Ephypite yeast has antagonist ability, made it easier to grow and adapt. This advantage made yeast growing faster in nature habitat [16].

Application of yeast earlier than pathogen has advantages on adaptation. Pathogen that inoculated after yeast application prone to lack in nutrition and spaces for growth. Antagonist yeast was applicated 8 hours earlier, showed higher antagonist ability to reduce width pathogen colony [17]. Candida farmata applicated 24 hours earlier can induct plant resistance against pathogen attack. It happened because yeast inducted chitinase enzyme activity and damaged pathogen compound [15]. In this observation, yeast and pathogen application had been done almost at the same time. It indicated that yeast cell had not been adapted with the new environment, then disease incidence level and incubation phase had not reduced.
Infection advanced by the ripening phase. It caused by nutrition availability for pathogen. The ripening fruit has rapid infection phase and it influence incubation pathogen phase [3]. Conidia can germinate for 4 hours and obtained appressorium for 20 hours. Direct infection was occurred for $24-48$ hours and caused the closed cells to be hypersensitive and obtained red-brown spot. It would be on latten condition until ripening. Latten condition caused by the host compound that made dormant appressoria [18, 19, 20].

On Figure 2 and 3 showed different incidences disease level. Incubation phase on Kepok variety was longer than Ambon variety. C. musae infection depends on ripening phase and banana variety. Bananas used in this research were fruits with ripening index 6 . On this condition, banana has character yellow peel and smooth. On ripening condition, biochemistry changes play on important role for pathogen. On banana, insoluble starch has changed to soluble starch. Then, glu- 
cose compound concerned resistance of host against pathogen colonization. It caused postharvest disease. In the other way, unripe banana has its own resistance against $C$. musae. It forms antifungal component, that could restrain and resist pathogen infection attack [18]. Banana variety, differentiated based on nutrition compound and the thickness of peel. Nutrition on Kepok variety is higher than Ambon variety, but Kepok peel is thicker than Ambon variety in ripen condition. Infection will be slow on Kepok variety because Kepok has thick and tight peel under ripening condition.

\section{Conclusion}

According to this observation, a conclusion is derived that thermotolerant yeasts can be obtained from Kepok and Ambon banana varieties. From Ambon obtained Candida sp., and from Kepok obtained Pichia sp. and Metchnikowia sp.

Banana varieties treatment gave significant effect for disease incubation phase and incidence disease level, whereas yeast treatment and combination of yeast and banana variety did not have any effect on disease incubation phase and incidence disease level.

\section{Acknowledgment}

\section{References}

1. Schisler DA, Jenisiewicz WJ, Boekhout T, Kurtzman CP (2011) Agriculturally important yeast: Biological control of field and postharvest disease using yeast antagonists, and yeast phathogens of plants the yeast. In: Kurztman CP, Fell JW, Boekhout T (Eds.) The yeast a taxonomic study volume 1 fifth edition. London, Elsevier. pp 45 - 52.

2. Prabawati S, Suyanti D, Setyabudi A (2008) Teknologi pasca panen dan teknik pengolahan buah pisang. Jakarta, Balai Besar Litbang Pasca Panen Pertanian.

3. Rumahlewang W, Amanupunyo HRD (2012) Patogenesitas Colletotrichum musae penyebab penyakit antraknosa pada beberapa varietas buah pisang. Jurnal Agrologia 1 (1): 76 - 81.

4. Sadat A, Tamrin S, Cicih (2015) Pengaruh pemeraman menggunakan batu karbit (CaC2) terhadap sifat fisik dan kimia buah pisang ambon kuning (Musa paradisiaca var. sapientum (L.) Kunt). Jurnal Rekayasa Pangan dan Pertanian 3 (4): 417 423.

5. Muhibuddin A (2009) Kajian hubungan populasi Glomus fasciculatum dengan faktor lingkungan. AGRIVITA, Journal of Agricultural Science 30 (1): 56 - 63.
6. Nurhalimah S, Nurhatika S, Muhibuddin A (2015) Eksplorasi Mikoriza Vesikular Arbuskular (MVA) indigenous pada tanah regosol di Pamekasan, Madura. Jurnal Sains dan Seni ITS 3 (1): $30-34$.

7. Li Z, Vizeacoumar FJ, Bahr S, Li J et al. (2011) Systematic exploration of essential yeast gene function with temperature-sensitive mutants. Nature Biotechnology 29 (4): 361 - 367.

8. Kardos L, Juhasz A, Palko GY et al. (2011) Comparing of mesophilic and thermophilic anaerobic fermented sewage sludge based on chemical and biochemical test. Journal of Applied Ecology and Environmental Research 9 (3): 293 - 302.

9. Bergman LW (2001) Growth and maintenance of yeast. In: MacDonald PN (Ed.) Method in molecular biology volume 177 two hybrid systems: Methods and protocols. New Jersey, Humana Press Inc. pp 9 - 32.

10. Sugipriatini D (2009) Potensi penggunaan khamir dan kitosan untuk pengendalian busuk buah Lasiodiplodia theobromae (Pat.) Griffon \& Maubl. (syn. Botryodiplodia theobromae Pat.) pada buah mangga selama penyimpanan. Master Thesis. Institut Pertanian Bogor.

11. Yarrow D (1998) Method for the isolation, maintenance, and identification of yeast. In: Kurtzman CP, Feel JP (Eds.) The Yeast a taxonomic study. Amsterdam, Elsevier. pp 77 - 100.

12. Fitriati Y, Wiyono S, Sumaraw IO (2013) Khamir antagonis untuk pengendalian penyakit antraknosa pada buah avokad selama penyimpanan. Jurnal Fitopatologi Indonesia 9 (5): 153 - 159. doi: 10.14692/jfi.9.5.153.

13. Puspitasari AE, Abadi AL, Sulistyowati L (2014) Potensi khamir sebagai agen pengendali hayati patogen Colletotrichum sp. pada buah cabai, buncis, dan stroberi. Jurnal HPT 2 (3): 92 101.

14. Dhiani H P (2012) Kemampuan antagonisme khamir filum Ascomycota dari tanaman saeh (Broussonetia papyrifera Vent.) asal Trowulan terhadap Aspergilus spp. UICC. Bachelor thesis. Universitas Indonesia.

15. Spadaro D, Droby S (2015) Development of biocontrol products for postharvest diseases of fruit: The importance of elucidating the mechanism of action of yeast antagonist. Journal of Trends in Food Science and Technology 47: 39 - 49. doi: 10.1016/j.tifs.2015.11.003.

16. Kora, C, McDonald M R, Boland GJ (2008) New progress in the integrated management of sclerotinia rot of carrot. In: Aiancio AK, Mukerji G (Eds.) Integrated management of diseases caused by fungi, phytoplasma and bacteria. New York, Springer Science. pp $243-270$.

17. Fenina S (2012) Kemampuan antagonisme khamir filum Basidiomycota dari tanaman saeh (Broussonetia papyfera Vent.) asal Trowulan terhadap Aspergilus spp. UICC. Skripsi. Universitas Indonesia. Depok.

18. Droby S (2011) Postharvest pathology of tropical fruit and strategies for decay control. In: Yahia EM (Ed.). Postharvest biology 
NPRA A Muhibuddin, DM Sholihah, 2019 / Potential of Wild Yeast from Banana to Control Colletotrichum musae

and technology of tropical and subtropical fruits volume 1: Fundamental issues. Cambridge, Woodhead Publishing. pp 194 216.

19. Ara I, Razwana H, Al-Othman MR, Bakir MA (2012) Studies of actinomycetes for biological control of Colletotrichum musae pathogen during post harvest antracnose of banana. African
Journal of Microbiology Research 6 (17): 3879 - 3886. doi: 10.5897/AJMR12.088.

20. Silva CFB, Michereff SJ (2013) Biology of Colletotrichum spp. and epodemiologi of anthracnose in tropical fruit trees. Journal of Revista Caatinga 26 (4): 130 - 138. 
This page is intentionally left blank. 